NBER WORKING PAPER SERIES

\author{
GOVERNMENT INTERVENTION IN \\ THE MARKETS FOR EDUCATION AND \\ HEALTH CARE: HOW AND WHY?
}

James M. Poterba

Working Paper No. 4916

\author{
NATIONAL BUREAU OF ECONOMIC RESEARCH \\ 1050 Massachusetts Avenue \\ Cambridge, MA 02138 \\ November 1994
}

This paper was prepared for the NBER Conference on "Individual and Social Responsibility." I am grateful to David Cutler, Martin Feldstein, Claudia Goldin, Jonathan Gruber, Roger Noll. Julio Rotemberg, Richard Zeckhauser, and especially Victor Fuchs for helpful discussions on these issues. This research was supported by the NSF and the Robert Woods Johnson Foundation. This paper is part of NBER's research programs in Health Care, Labor Studies and Public Economics. Any opinions. expressed are those of the author and not those of the National Bureau of Economic Research.

() 1994 by James M. Poterba. All rights reserved. Short sections of text, not to exceed two paragraphs, may be quoted without explicit permission provided that full credit, including (c) notice, is given to the source. 
NBER Working Paper \#4916

November 1994

\section{GOVERNMENT INTERVENTION IN THE MARKETS FOR EDUCATION AND HEALTH CARE: HOW AND WHY?}

\section{ABSTRACT}

Education and health care are the two largest government expenditure items in the United States. The public sector directly provides the majority of educational services, through the public school bureaucracy, while most public support for health care is channelled through a system of tax-supported government payments for services provided by private providers. The contrast between public policies in these markets raises a host of questions about the scope of government in a mixed economy, and the structure of policies for market intervention. This paper examines how two standard arguments for government intervention in private markets, market failure and redistribution, apply to the markets for education and medical care. It then considers the "choice of instrument" problem, the choice between intervention via price subsidies, mandates, and direct public provision of services in these markets. Economic arguments alone seem unable to explain the sharp divergence between the nature of public policies with respect to education and medical care. Moreover, there is virtually no evidence on the empirical magnitudes of many of the key parameters needed to guide policy in these areas, such as the social extermalities associated with primary and secondary education or the degree to which adverse selection in the insurance market prevents private insurance purchase.

James M. Poterba

Department of Economics

M.I.T.

E52-350

Cambridge, MA 02139

and NBER 
Education and health care are the two largest government expenditure items in most developed economies. In 1991, total government spending on primary and secondary education in the United States totalled $\$ 219$ billion, and another $\$ 96$ billion was spent on public colleges and universities. Education outlays represent nearly thirty percent of government purchases of goods and services. Direct government health care spending totalled $\$ 316$ billion, and another $\$ 60$ billion of foregone revenue was attributable to deductions and exemptions of health-related items linder the income tax.

There are fundamental differences in the government's role in the health and education sectors of the United States economy. State and local governments are the direct providers of the majority $(92 \%)$ of primary and secondary educational services. The service providers are government employees, with salaries set through a partly political process, and decisions about methods of production such as classroom activities and curriculum are made by a quasi-political government bureaucracies. Competition between alternative providers of educational services occurs largely through competition between communities for potential residents.

In health care, although federal, state, and local governments ultimately pay for more than forty percent of health outlays, they are direct providers of relatively little health care. While state and local governments operate some hospitals, and the federal government administers the VA medical network, most health care providers work in the private sector. Various government programs and policies nevertheless substantially reduce the cost of medical care for many consumers. Medicare and Medicaid, the federal government's programs to provide health care services to the 
elderly and the indigent, are essentially tax-supported systems of government payments for services provided in the private market. In addition, the current income tax code subsidizes medical outlays by households who are neither elderly nor poor. thereby altering the price of health services.

The contrast between public policies in these two markets raises a host of questions about the scope of government in a mixed economy. Even a cursory review of current policies yields paradoxes. For example, why is most child care for preschoolers in the United States provided through a system of family and private market transactions, while primary and secondary education is provided directly by the government? Why is the public sector's role in higher education substantially smaller than its role in elementary education? Why did the Gl Bill, which provided health care and educational benefits for veterans of World War II, rely on a federal bureaucracy (the $V A$ ) to directly provide health care, while relying on a variant of a voucher system and private providers with respect to education? Why does the federal government directly produce health care services for veterans, while relying on private providers for those who receive benefits under Medicare and Medicaid? Why are there substantial differences across localities in the degree of public vs. private provision of some services?

These questions relate broadly to the "choice of instrument problem," the question of how government should intervene in a market if such intervention is deemed necessary. Although public finance textbooks, such as Rosen (1992) and Stiglitz (1988), begin by explaining that market failure and redistributive 
considerations can justify government intervention in a market economy, there is remarkably little discussion of what types of policies are justified. Empirical evidence on the importance of potential market failures, and the distributional consequences of various interventions in the markets for education and health care services, is particularly scarce. Moreover, economic factors alone are unlikely to explain the observed structure of public policy, which is due in significant part to historical and political influences.

This paper explores the "choice of instrument" problem with particular application to the markets for education and health care. It is divided into five sections. The first outlines the traditional market failure arguments that neoclassical economists marshall to support of public intervention in private markets, and discusses the application of these arguments to education and health care. Section two explores the link between goals of redistributive justice and public policies in these areas. Both education and health care have been described as "basic rights" in some contexts, suggesting that these services should not be allocated on the basis of ability to pay.

The third section examines the comparative merits of three potential policy interventions: price subsidies, including the special case of full public payment for purchases in the private market, public mandates for private provision, and direct government provision. It highlights conditions under which each of these potential instruments will be successful in achieving particular policy objectives, as well as situations in which each instrument may fail. Section four describes the current 
4

structure and historical evolution of public policies toward education and health care in the United States, and considers the degree to which the market failure and redistributive considerations described in the earlier sections can account for these policies. The concluding section outlines areas of uncertainty where further work is needed to evaluate alternative policy instruments.

\section{Market Failures in the Markets for Education and Health Care}

Market imperfections may take many forms: the consumption of some goods may impose external benefits or costs that are not reflected in their market prices, informational asymmetries or other factors may lead to the non-existence of markets for some products, or consumers may not have the information necessary to make appropriate choices. This section considers the sources of market failure in markets for education and health care.

\subsection{Market Failures with Respect to Education}

Many of the classical economists broke with their usual laissez faire view of the appropriate role of government when confronted with questions of education policy. In The Wealth of Nations, Adam Smith argued that "The state derives no inconsiderable advantage from [the education of the common people. If instructed they are $\ldots$... less liable to the delusions of enthusiasm and superstition, which among ignorant nations, frequently occasion the most dreadful disorders." (Book V. Part III, article 2) This reference to society-wide externalities associated with the education 
of each individual is only one of the potential market imperfections that might warrant government intervention in the market for schooling.

The first, and most commonly alledged, source of market failure with respect to education is the presence of externalities from schooling. This argument has been made in many ways; Cohn and Geske (1990) provide an overview. Some claim that an educated electorate is vital to a successful democratic society, for example because it permits individuals to keep records, file tax returns, and evaludte canipaign material. Others argue that an educated workforce is critical for the adoption of new technologies and for improving not just an individual's productivity, but that of his or her co-workers. Yet a third externality argument holds that there is a negative relationship between education and crime, so that widespread education will reduce crime and the associated social disruption.

A related externality argument, that applied with particular force to the nineteenth century United States, is that education assists in socializing many diverse immigrant groups. This argument is probably specific to public education: providing the same level of education, though various parochial schools, might have had a smaller effect on social integration. Widespread public education during this period probably helped the "melting pot" to function, and exposed groups from different national backgrounds to the civic structure and related aspects of the United States.

Each of these arguments suggests that private spending on education contributes to a public good. If parents ignore the externalities associated with education in deciding how much to spend on their child's education, education 
spending will fall below the socially efficient level. Public policies designed to increase educational attainment therefore have some prospect for raising social welfare.

A second potential rationale for government intervention arises because minors, who are the usual recipients of education, are not responsible for deciding how much schooling they will obtain. This responsibility falls to their parents, who also bear the costs of education. Since the benefits of education accrue primarily to the children who receive it, the level of spending on education depends critically on the degree of parental altruism. If parents place a low value on improvements in their childrens' future earning potential, then they may underinvest in their children, and governmient intervention might be justified on the ground that it protects children from decisions by their parents. ${ }^{1}$

One difficulty with this argument is that it could be invoked to justify state intervention in virtually all aspects of child rearing. Can parents be trusted to feed their children properly? To provide the appropriate amount and type of playthings and other stimuli to early development? It is not clear, as West (1970) notes, that the risk of parental underprovision of education is any greater than the risk of underprovision of many other important developmental inputs.

A third market imperfection that may be relevant for education decisions

\footnotetext{
'It is at least possible that some parents may be more concerned with their children than a social planner would be. Parents may also misperceive the value of spending on their children, measured in terms of the corresponding increment to future income or utility, or be concerned primarily with the relative status of their children, as discussed in Frank (1995). Any of these factors might lead to overprovision of private education.
} 
involves capital market constraints. If some households face borrowing constraints that limit their total access to credit or cause them to face borrowing rates above the economy-wide marginal product of capital, then even parents whose altruism matched that of the social planner might underinvest in their children. Because loans to obtain education are not backed by tangible collateral, they are often difficult to obtain in private credit markets.

A fourth market imperfection, one that applies most strongly in small communities with a limited number of children to educate, is the presence of fixed costs in educational production. The marginal cost of adding another student to a classroom is lower than the average cost of each student's education. Such economy of scale arguments, which may also apply to consumption of some types of specialized services in large school districts, provide an efficiency argument for group consumption of educational services. This does not necessarily imply that the public sector must provide education.

Although it is relatively easy to construct a list of imperfections in the market for educational services, it is extremely difficult to guantify their importance. How many parents, for example, would neglect their childrens' education? Moreover, while there are undeniably some externalities associated with education, primary and secondary education also yield very high private returns. The central question is therefore whether there are externalities associated with education above the level that parents would choose in a private market. Yet virtually none of the empirical evidence on the economic returns to education is directed at this issue. 
Optimal government policy must balance the gains associated with the partial or complete correction of market failures against the costs of the policy and its associated distortions. Virtually any government intervention, whether through price subsidies or through public production of services, distorts behavior. Peltzman (1973) and Sonstelie (1982) are among the small group of studies that have explored the inefficiencies created by the current policy of free public provision of education. Peltzman (1973) shows that free public schools distort parental choice, and lead some parents who would otherwise have chosen schools better than their local public schools to send their children to those schools. This is because lower quality, but free, public schools may on balance be more attractive to parents than higher quality schools for which they must pay tuition.

Sonstelie (1982) also concludes that there is a significant efficiency cost to free public schools, but his argument relies heavily on his assumption that private schools are more efficient providers of educational services than their public school counterparts. ${ }^{2}$ Neither of these studies considers the potential costs associated with public rather than private production of education services. Further work on the private demand for education is important for evaluating a number of current educational reform proposals, such as those for school vouchers and other means of introducing more competition into the educational marketplace.

\footnotetext{
${ }^{2}$ It is difficult to control for the differences in the attributes of public and private school students in making such efficiency comparisons. Even if private schools appear to be more efficient when they are educating only a small and self-selected part of the population, they could be no more efficient than existing public schools if their student input was the same.
} 


\subsection{Market Failures with Respect to Health Care}

While potential market failures with respect to education center on externality issues, those with respect to health care focus on information. Arrow's (1963) seminal analysis emphasizes several potential sources of market imperfection. including asymettric information between consumers and providers of health care services as well as uncertainty about current and future needs for medical services. Uncertainty leads individuals to demand health insurance, and raises the question of whether the insurance market satisfies the conditions of perfect competition. Health care suppliers may also be imperfectly competitive, creating a further potential market failure.

The first potential difficulty with the health care market arises trom the lımited information that patients possess about the benefits associated with various medical treatments. The effects of most treatments are random to some degree, and patients are not well equipped to evaluate the relevant information on treatment effects. Individuals rarely confront the same major illness several times, so there is little opportunity to acquire information about the relative performance of different treatment regimens. Moreover, since purchasing medical care typically involves purchasing the services of an expert, quality evaluation is critical but very difficult. ${ }^{3}$ Combining information from many different patients is problematic because of potential differences in their presenting conditions, so consumers may have no

\footnotetext{
${ }^{3}$ Richard Zeckhauser also notes that most medical care is a "preclusive good." Choosing to have an operation performed by one physician effectively precludes other physicians from performing this procedure.
} 
objective measures of physician quality. These factors suggest that patients may not make rational choices about which health care services to consume.

The unpredictable nature of many medical expenses, which leads to a demand for insurance, gives rise to a separate set of market imperfections. Risk averse individuals can raise their expected utility by purchasing actuarially fair medical insurance. But once they have insurance that shares in the cost of their medical outlays, their demand for medical care will be distorted because they no longer face the full cost of their health care services. The resulting moral hazard problem can impair the functioning of insurance market and leads private insurers to offer less than full insurance.

A relatad problem with the private medical insurance market turns on adverse selection in purchasing population. Rothschild and Stiglitz (1976) and Wilson (1980) have shown that when potential insurance buyers are heterogeneous, adverse selection can lead to the disappearance of the markets for some types of insurance, hence to market failure. The government has an important advantage relative to private insurers in creating health insurance policies: it can compel individuals to participate. Compulsion enables the government to insure everyone at the actuarially fair rate for the entire population.

There are other potential imperfections in the private health care market. Most medical services are not supplied under perfectly competitive conditions. Many hospitals and some specialized physicians may be monopolists in their local markets, there may be collusion among the various doctors in an area, and there are a range 
of government subsidies to the production of health care professionals that cause deviations from standard efficiency conditions. Externalities may also arise in the consumption of medical care. Although small for most kinds of health care services, such externalities are present with respect to innoculation against infectious diseases and potentially with some other types of care as well.

In the health care market, as with education, it is easier to list potential market imperfections than to quantify their substantive importance or to link them to potential market interventions. For example, while the 1994 Economic Report of the President cites evidence that a non-trivial fraction of medical procedures are not medically necessary, it is not clear that these procedures are the result of informational or other problems. While many analysts agree that there are imperfections in the health insurance market, and as Aaron (1994) notes, private insurers have evolved a variety of devices such as experience rating, coverage waiting periods, and exclusions nf preexisting conditions to address adverse selection problems, quantitative evidence on the substantive consequences of adverse selection remains elusive.

The vast majority of U.S. citizens currently obtain health insurance in private markets. A significant number of the uninsured have access to insurance, but choose not to purchase it. ${ }^{4}$ Long and Marquis (1992) show that low-wage, part-time workers are particularly unlikely to purchase employer-provided insurance. They

\footnotetext{
${ }^{4}$ Adverse selection may lead insurers to offer some kinds of policies at very high loads relative to their actuarial risk. Even if consumers could in principle buy such policies, but do not, there may be a case for government intervention to improve the workings of such markets. Thus the availability of an insurance policy per se does not indicate that adverse selection is not a problem.
} 
observe that one reason small firms with substantial numbers of such workers do not offer health insurance may be that their workers do not demand such coverage. There is virtually no empirical evidence linking various types of market failure to the heaith care utilization decisions of households.

\section{Redistributive Arguments for Government Provision of Education and Health Care}

While efficiency concerns are one rationale for public policies that intervene in the markets for education and health care, they are not the sole or even the primary rationale for existing programs. ${ }^{5}$ Redistributive concerns also play an important role. With respect to both education and health care, many subscribe to what Tobin (1970) labelled "specific egalitarianism:" the view that access to these services should not be conditioned on income. This section explores the redistributive arguments for government intervention in these markets in more detail.

At the outset, one must ask why redistribution should be linked to particular goods, rather than carried out with income transfers. Since the utility gain from transferring a given bundle of goods to a recipient is always less than the recipient's gain from receiving the cash value of these goods, there is a strong a priori argument for separating redistribution from the provision of particular goods.

While this argument applies for each recipient, it may not apply to a transfer

\footnotetext{
${ }^{5}$ Zeckhauser (1986), in an essay that explores issues similar to those raised here, concludes that "only a small portion of [the vast subsidies and direct payments for health care and education] can be justified primarily on the basis that they provide public goods or remedy market failures.(p.47)"
} 
program as a whole. There are a number of reasons why in-kind programs or subsidies to the consumption of particular goods can be more efficient than income redistribution, even when the consumption of particular goods does not generate externalities. First, in-kind transfers may be better than comparable cash transfers at channelling resources to a target population. Nichols and Zeckhauser (1982) and Besley and Coate (1991) argue that in-kind programs may help the government to distinguish the truly needy from other potential program beneficiaries. Second, in-kind programs may be attractive policies when policy-makers seek to impose their preferences on individuals. In education, for example, public policies specify the amount of schooling a child must receive.

A final explanation for the use of in-kind rather than cash redistribution is political, rather than economic. More political coalitions support in-kind programs than equivaient spending on cash transfers, because in-kind goods and services are supplied by identifiable industries. Thus, there are interest groups that benefit from in-kind redistribution. Teachers and health care professionals may support expanded government transfers in their respective markets, even if they do not support expanded income redistribution in general. ${ }^{\theta}$ West $(1967,1970)$ argues that even if public provision of education was needed in the United States in the mid-nineteenth century to overcome a lack of infrastructure for delivering educational services, it was not needed for long. West (1967) identifies support from several organized interest

${ }^{6}$ Doctors, however, opposed the passage of Medicare and Medicaid in 1965, on the grounds that these programs were the first steps to socialized medicine. 
groups, including teachers, as essential to the continued growth of public schools.

\subsection{Redistributive Concerns and Education}

Providing "equal opportunity" is one of the objectives of current policies with respect to education. Since parental resources are unequal, even if parents value their children's lifetime utility in the same way as the social planner and face wellfunctioning capital markets, there will be differences in the level of education that children would receive in a private market for education. Such differences may translate into differences in lifetime earning opportunities, which some argue against as unfair because they are beyond the childrens' control. The public sector must therefore ensure access to adequate education for all, either by supplying a basic educational services package, or through a system of income-linked subsidies of the price of education. Zeckhauser (1986) notes that equality can be defined in many, sometimes inconsistent, ways: equality of the price at which different households can purchase a given service, equality of the quantity of service consumed by different households, and equality of the outcome of service consumption are three examples.

In the United States, public education has historically been a responsibility of local government, although there has been a trend in the last half century toward greater centralization of finance at the state rather than the local level. For the 199091 school year, local revenue sources accounted for $46.5 \%$ of public spending on primary and secondary education, compared with $47.3 \%$ from state governments and $6.2 \%$ from the federal government (Digest of Educational Statistics, 1993, Table 
156). In 1947-48, local governments provided $57.9 \%$ of the money, while two decades earlier, in 1929-30, the local share was $82.7 \%$.

Local financing raises important qualifications to the redistributive power of public spending on education. Because communities differ in their tax bases and their willingness to impose taxes, there is substantial variation across places in spending levels. Although a number of court decisions during the last three decades have weakened the link between educational spending and property taxes on the grounds that the property tax base is highly unequal across communities, disparities across jurisdictions remain. Wealthy communities spend more on schools than poorer communities, so the existing system of locally-provided education is not as redistributive as it would be if a higher level of government were the primary service provider.

Since the incidence of local taxes is primarily on the residents of local jurisdictions, at least when individuals are free to move, local public provision of education is tantamount to taxing all residents of a jurisdiction to pay for the average level of educational consumption in the community. This policy can redistribute resources within a community, but it is a weak device for redistributing resources between those in different communities. Milton Friedman (1962) argues that the present combination of local government provision of education and reliance on local property tax finance makes it more difficult for low-income families to purchase highquality education. This is because consuming high-quality public education usually requires purchasing an expensive house in a school district with high-quality schools. 
This can require a much greater outlay of resources than simply purchasing higher quality education.

\subsection{Redistribution and the Government's Role in Health Care}

"Specific egalitarianism" also applies to universal access to health care. The recient health care debate provides many examples of policy-makers and political leaders who believe that access to adequate health care should not be conditioned on ability to pay, and there seems to be substantial popular support for this view. Whether the stronger claim, that those with higher incomes should not have access to better care than those with low incomes, commands support is less clear. In any event, redistributive objectives play a central part in the design of government health care policy. Gornick et al. (1985) report that in 1963, on the eve of Medicare's passage, only $56 \%$ of those aged $65+$ had health insurance. The insurance rate for younger age groups was substantially greater, even though the need for medical care was greater among the elderly population, and this was one of the factors contributing to support for Medicare.

Government policies to subsidize health insurance and health care redistribute along at least two dimensions. First, as with most redistributive programs, such subsidies transfer resources to those with relatively low incomes. However, the with respect to medical care one must also distinguish between the ex ante value of government insurance, before learning about a household's medical needs, and the ex post value of the insurance, after such needs are observed. The second aspect of 
redistribution within government health programs is a transfer from those who do not require much medical assistance to those who do. Because health outlays are highly concentrated, with estimates for 1994 suggesting that $20.3 \%$ of all health spending will be accounted for by the $1.6 \%$ of the population with more than $\$ 30,000$ in spending, and $51.3 \%$ of spending will be done by the $8.1 \%$ of the population with more than $\$ 10,000$ in health care outlays, the second form of redistribution can be quite important. ${ }^{?}$

Even if government subsidies to health insurance were not age-related, the agespecific pattern of medical care demand would lead such subsidies to redistribute to the elderly. The current structure of health care programs in the United States, with eligibility for Medicare conditioned on reaching age 65 , accentuates this redistribution. Such policies both raise the standard of living of elderly households, and they also may reduce the financial and other burdens on the children of the elderly who would otherwise need to devote attention and resources to their care. ${ }^{8}$

The intergenerational pattern of benefits associated with medical care for the elderly is an important but relatively unexplored issue, and one that may be critical to

'Economic Report of the President, 1994, p. 143. These statistics include all medical care spending, including preventative, routine, and acute care. Spending on acute care is even more concentrated, with Aaron (1995) reporting that five percent of the population accounting for more than half of the outlays in a given year.

${ }^{8}$ Davis and Schoen (1978) explicitly mention reduced burdens on middle-aged children of elderly households as one of the benefits of Medicare. Cutler and Sheiner (1994) show that government provision of nursing home care displaces a substantial amount of care that would otherwise have been provided by children. 
explaining the political support for these programs. ${ }^{9}$ Most individuals in middle-age have surviving parents. For example. Himes (1994) shows that for a 35 year old white woman in 1987, the probability that she had two living parents was approximately .60 . The probability that she had at least one living parent was greater than .90 , substantially higher than the probability that she had at least one child $(.81)$. The probability that a white woman has at least one living parent does not fall below one half until she reaches her early 50 s. Thus altruism from children to parents can explain political support among middle-aged individuals with respect to health care policy for the elderly. It is also possible that part of the increased taxes required to finance such benefits will be offset by higher bequests from parents who received transfers and therefore did not have to spend-down their wealth during retirement.

\section{The Choice of Instruments: Subsidies, Mandates, \& Government Provision}

Why is the nature of government involvement in education and health care so different? In the health care market the government plays a largely financial role, purchasing health care services provided by the private market, while in the market for educational services, it is the single largest supplier of the service in question. This section considers the structure of public sector interventions in private markets, given that there is a market failure or redistributive justification for some market

\footnotetext{
${ }^{9}$ This question may be even more central to analyzing public support for provision of nursing home care rather than medical care.
} 
intervention.

The basic criterion that a social planner would use to choose a means of market intervention is clear: select that policy which provides the highest level of social welfare. In practice, policy choices involve important political aspects which may dwarf direct social welfare concerns. Suppressing political considerations for the moment, this section considers the factors that determine the relative merits of different policy instruments.

The choice among various alternatives depends not only on the market failure that motivates government intervention in private markets, but also on the costs of different methods of intervention and the capacity of government officials to obtain the information needed for successful intervention. These latter concerns suggest that even if there is a market failure, it may be optimal for the government not to intervene because the cost of government action would exceed the gains from remedying market failure. This possibility, "government failure," has been discussed by McKean and Minasian (1966) and Wolf (1986).

This section compares price subsidies, government mandates, and direct government service provision. It discusses the advantages and disadvantages of each. The next section describes actual polices toward education and health rare in the United States, and asks whether the various considerations described below can explain the structure of current policies. 


\subsection{Price Subsidies}

The textbook remedy for externalities that are not reflected in private choices is a "Pigouvian tax" that alters the price individuals face, so that their private choices will yield the socially efficient level of consumption. In practice, a range of public policies are available to alter the private cost of purchasing services such as education and medical care. These include tax subsidies, direct subsidies such as Medicare that involve government financing of most or all service consumption, and incentives to the production of services, such as grants to medical schools or interest-free loans for medical students.

The efficacy of price subsidies depends critically on the price elasticity of demand for the subsidized service. When this elasticity is low, when there is uncertainty about this elasticity, or when there is a wide divergence across households in this elasticity, then price subsidies may be an unattractive form of market intervention. Weitzman (1974) develops an argument of this form in his comparison of "prices vs. quantities" as alternative means of regulation.

There is no consensus on the empirical magnitude of the price elasticities of demand for education and medical care. Studies of the demand for education typically compare local public spending in different towns, and invoke the median voter model to argue that the each town's spending is the level demanded by the town's median voter. There are many potential difficulties with this approach, including the potential influence of political institutions such as Proposition 13 on local spending, and the problem of modelling the choice of local spending when 
jurisdictions are imperfectly competitive. Studies of this type usually yield relatively small estimates of the price elasticity of demand; Sonstelie's (1982) study of California, for example, suggests a value -.16.

In the medical care market, the central problem is the potential endogeneity of health insurance, which has an important effect on the net price of medical care services. Some of the most convincing empirical evidence to date on the price elasticity of demand for medical care is based on the RAND Health Insurance Experiment, a systematic social experiment that was conducted in four cities during the mid-1970s. In analyzing the resulting data, Keeler et al. (1988) report an elasticity of demand for total medical care of -.22 for households facing copayment rates of greater than 25 percent. The estimated demand elasticity for well-patient care is greater, -.43, while the elasticity for hospital care is -.14 .

Specific egalitarianism with respect to health care does not imply that all individuals should consume the same amount of medical care; some people need very little care in a given year. Rather, it implies equality of access, so that conditional on need, individuals have the same opportunity to receive care. This suggests that from the standpoint of public policy, a key parameter is the price elasticity of insurance demand rather than medical care demand. The demand for insurance is substantially more price sensitive than the demand for health care. Gruber and Poterba (1994) present evidence, based on changes in tax incentives for insurance purchase in the 1980s, suggesting that the price elasticity of insurance demand is hetwern - 1 and -? These estimates, which are based on the effects within several years around a tax 
reform that reduced the after-tax cost of insurance for the self-employed, may somewhat overstate the long-run elasticity of demand for insurance. They are nevertheless consistent with earlier studies using different methodologies, which also suggest large price effects on insurance demand.

These elasticity estimates suggest that price subsidies may have substantial effects on the demand for health insurance, they are not likely to have large effects on the consumption of education. This has direct implications for the choice of policy instrument: price subsidies to education may not be very successful in altering the quantity of services in the private market.

The principal advantage of price subsidies is that they preserve individual choice in selecting service providers and the level of services to be consumed. Such choice permits individuals to search for goods and services with qualities or other attributes that are well suited to their needs. If there is substantial heterogeneity in household tastes, then allowing individual choice can have a substantial positive effect on consumer welfare. ${ }^{10}$ The difficult case arises when recognizing this heterogeneity may exacerbate the market failures or inequality that public policy is designed to address.

One drawback with price subsidies is that they create incentives for households to re-categorize non-subsidized expenditures in an attempt to qualify them for the subsidy. This problem, the dual of the tax collection problem in which taxpayers

\footnotetext{
${ }^{10}$ This argument presumes that consumers are capable of making rational demand decisions, an assumption that may not hold with respect to some aspects of medical care.
} 
redefine taxable income into non-taxable forms, has two consequences. First, it means that the revenue cost of a price subsidy may be greater than the subsidy rate times the actual amount of the subsidized activity. Second, and significantly if the government's objective is to ensure that everyone consumes a minimal service level, the private market may create "sham transactions" that qualify for the price subsidy but do not achieve the government's goals.

Education illustrates the potential problem with sham transactions. If parents received subsidies for school spending, but "schools" were not well defined for this purpose, one could imagine a range of service providers who would comingle services for parents with educational services. Schools might, for example, organize family field trips that were of value to parents as well as children, and include the cost of these trips in tuition charges. The ease or difficulty of monitoring such sham transactions affects the desirability of using price subsidies to encourage service consumption.

Two additional problems deserve mention when subsidies are enacted as part of the tax system, as they are with some aspects of health care. First, because marginal tax rates are progressive, a subsidy that operates by allowing individuals to deduct certain expenditures from taxable income will have a larger marginal effect on the price paid by high-than by low-income households. Second, the effective subsidy rate in this case is affected by changes in the income tax system, changes which may bear no relation to changes in the rate of subsidy that is suggested by market failure considerations. 


\subsection{Government Mandates}

One alternative to price subsidies is a government mandate of that all households purchase a particular good or service. The recent discussion of "individual mandates" in the health reform debate provides an example: individuals would be required to purchase health insurance satisfying some criteria, but these policies could be purchased in the private market. Current requirements that employers purchase workers compensation insurance, and that children receive certain vaccinations before beginning elementary school, are examples of goverment mandates.

The primary advantage of mandates is that they ensure universal consunption, and they can be tailored to directly control levels of consumption. By mandating that all children in certain age groups attend an accredited elementary or secondary school, the government achieves at least one measure of equality in educational consumption. When concerns about equity in outcomes rather than opportunity motivate policies, mandates may be attractive policy instruments. Mandates can be open-ended, requiring all individuals to consume at least a certain amount of a service, or they may be closed-ended, specifying precisely the good or service that is to be consumed. The latter achieves a greater degree of equality across individuals, at the welfare cost of denying individual choice.

It is important to contrast the effects of price subsidies with the effect of government mandates in the framework suggested by Weitzman (1974). With pricebased instruments, at least ex ante, it is difficult to assess the quantity response to a policy. This makes such instruments unattractive in situations where there are 
substantial benefits to particular levels of service consumption, as might be the case with some levels of education or some types of innoculations. Mandates, with or without public service provision, solve this problem because they specify the level of service consumption, but they impose ex ante unknown costs on many individuals and firms.

A secondary advantage of mandates, which can be very important in the political economy of policy design, is that they can be designed to impose costs on individuals or firms without affecting government budgets. In times of fiscal stringency, such as the present, mandates may be particularly attractive to policymakers because they provide a mechanism for affecting real activity without spending money. Some popular discussions of public policy appear to exhibit confusion about the relationship between taxes and mandates, and there appears to be more political opposition to new taxes than to new mandates with economically equivalent effects. This is one of the reasons that mandates played a central role in the recent discussion of health care reform.

Mandates require a well-functioning private market for the mandated good or service if they are to succeed. Mandating that consumers purchase a service that is supplied under conditions of imperfect competition, for example, may have less favorable effects on social welfare than mandating purchase of a service that is competitively supplied. This issue arises with respect to health insurance mandates: if one of the market failures in health insurance is that adverse selection leads to missing insurance markets, a mandate without government insurance provision may 
be ineffective.

The economic analysis of government mandates is not as well developed as the analysis of taxes and price subsidies, but several points about the efficiency consequences of mandates nevertheless deserve mention. First, by mandating minimum levels of consumption but not altering the price of services for those who want to consume more than the mandate level, open-ended mandates avoid distorting the behavior of higher-consumption households. Summers (1989) emphasizes this point in his discussion of employer mandates. Second, assuming that individuals must pay to satisfy the mandate either by purchasing the mandated good or service, or through reduced wages if the mandate affects employers ${ }^{11}$, then a mandate is a form of "benefit tax." The welfare cost of the mandate depends on the difference between the amount the individual values the mandated good and the cost of purchasing this good. At least in some cases, the efficiency cost of a mandate can be substantially smaller than the efficiency cost of tax-financed government provision of the service. Mandates may therefore be attractive in situations where total private spending on a good is large, but the government wants to increase this spending without transferring all of the initial outlays into the government sector.

\footnotetext{
${ }^{11}$ Gruber (1994) summarizes previous work, and presents new evidence on, how wages adjust to government mandates that firms provide certain benefits to their workers. When mandates apply only to a sub-group of employees, wages may decline for some workers who do not benefit from the mandate, and they may not decline by the full amount of the mandate's cost for some workers who do benefit.
} 


\subsection{Public Provision}

A third means of encouraging consumption of particular services involves direct public production. This could be combined either with a regime in which service recipients do not pay, and costs of production are covered through tax revenues, as with education, or with a regime in which consumers are charged when they purchase government produced goods and services. The Government Printing Office and state universities are examples of the latter system. Government production can be, but need not be, coupled with a mandate for consumption.

Public provision differs from price subsidies and mandates in that it gives government greater control over the nature of the services individuals consume. This can also be achieved in the other cases by regulating the product that is subsidized or mandated, but in some cases the costs of regulation may make this an unacceptable strategy. In the case of education, for example, one reason for substantial government production may be the difficulty of specifying a required school curriculum for non-government providers, although the existence of accredited private schools raises some question about this explanation. Public provision can also be a device for restricting potentially wasteful private competition among consumers, which Frank (1995) suggests may apply to some extent with respect to educational and other services consumed by middle- and upper-income households.

Government control may also be important when distributional issues that might be difficult to resolve in the private sector arise in the allocation of services. in education, for example, there may be important externalities across children within a 
classroom or school. ${ }^{12}$ How would the private market handle the disruptive child who imposes negative externalities on other children? Possibly by excluding him from the school, or by charging him a premium to attend school. If these responses seem unacceptable to notions of justice or equal opportunity, it may be necessary for the government to control the production process.

A distinct reason for government provision of some services is that profitmaking enterprises may place their bottom lines ahead of concerns about quality or appropriateness of service, undermining public confidence in their services. In such situations, non-profit providers may emerge or the public sector may assume responsibility for service delivery. ${ }^{13}$ At a time when public confidence in government seems very low, however, it is difficult to know whether consumers would prefer a for-profit hospital, which may deliver services they don't need but that generate profits, or a public hospital, which may deliver low-quality versions of services they do need.

There are several arguments against public service provision. One is that the government is characterized by "production inefficiency" as a service provider. There have been numerous studies of the relative efficiency of public and private provision,

\footnotetext{
${ }^{12}$ The extent of peer group effects and within-classroom externalities in the educational process is controversial. For example, Henderson, Mieskowski, and Sauvageau (1978) find positive externalities from being exposed to high-achievement students; other studies find weaker results.

${ }^{13}$ Non-profit providers avoid the charge of profit-maximization service delivery, but they may also be subject to some of the production inefficiencies that may characterize public production. Hansmann (1995) discusses the role of non-profits in health and education, and outlines potential sources of inefficiency in their operation.
} 
surveyed for example by Vining and Boardman (1993). These studies, while not conclusive or uniform, suggest that government production is less efficient than private production, although the comparison between government production and nonprofit production, common in education and health care, is less clear. Bureaucrats who do not face the discipline of a competitive market may make inefficient choices with respect to factor inputs and their choice of output.

A brief summary of the state of research comparing efficiency at public and private health care facilities illustrates the lack of consensus. Lindsay (1976) compares various measures related to productivity at VA and private hospitals. The findings are mixed: lengths of stay for given procedures are longer at VA hospitals, but the staff-to-patient ratios are also significantly lower, in contrast to the inefficient input hypothesis. Becker and Sloan (1985) analyze data from the American Hospital Association's 1979 Survey of Hospitals on for-profit, non-profit, and government hospitals. They do not find any pronounced differences in hospital costs across forms of ownership. Schulz, Greenley, and Peterson (1984) compare the costs of public and private mental health services, and contrary to the earlier hospital studies, they find substantially lower costs for private sector providers. The existing literature on hospital costs is not conclusive, but it is far richer than the literature on the costs of public versus private education. Further work on the relative efficiency of different forms of ownership in both health and education is therefore is needed to judge the costs of public production of services.

A second disadvantage to public provision is the absence of any objective 
standard for which services should be provided. For a profit-maximizing firm, services that generate profits will be provided. But for a tax-supported public institution, there are no such guidelines, and there is a resulting risk of over-provision of services, or providing the wrong services.

A third disadvantage, which applies when publicly-provided services are taxfinanced, involves the efficiency cost of raising revenue. If total government spending to provide a given set services is $C$, but this amount is raised through taxes, then the cost imposed on the private sector is $(1+\lambda) C$, where $\lambda$ is the marginal deadweight loss of raising tax revenue. For the current United States tax system as a whole, estimates suggest a value of $\lambda$ near .30. Ballard, Ballard, Shoven, and Whalley (1985) provide support for this estimate. This efficiency cost of taxation compounds the efficiency lost in the production process.

\section{Mixing \& Matching Instruments: Current Policy Toward Education \& Health Care}

Actual government intervention in the markets for education and health care involves each of the three policy instruments described above. This section describes the nature and evolution of government policies in both of these areas, and then tries to evaluate whether efficiency considerations, redistributive objectives, or other factors explain the nature of observed policies.

\subsection{Government Involvement in Markets for Education}

Public provision as well as mandates and price subsidies are evident in the 
market for education. Local governments are direct suppliers of most primary and secondary educational services. Yet with respect to pre-elementary education (child carel, the government's role as a provider is limited. There are some price subsidies to consumers, and some regulations on private market providers. In higher education, there are price subsidies through a variety of student loan programs, which also alleviate capital market constraints, but state governments are also direct producers of higher educational services.

Before describing policies toward primary and secondary education, it is important to note that it is difficult to separate child care and education on any a priori basis. There is evidence that much of a child's performance in school is predictable from his or her preparation for elementary school, i.e., from what would traditionally be labelled "child care." This sub-section therefore describes government policies toward child care as well as primary, secondary, and higher education.

The vast majority of care for children under the age of 5 is provided in the home and/or by relatives. In 1991, 30.3\% of children were cared for at home by a relative, $5.7 \%$ at home by a nonrelative, $13.1 \%$ in another home by a relative, $17.9 \%$ in another home by a non-relative, and $23 \%$ were cared for in an organized child care facility. ${ }^{14}$ The majority $(62 \%)$ of the 2.9 million children enrolled in nursery school programs were in private sector programs. Thus the overwhelming majority of care for children who are not yet old enough to attend elementary school was provided

\footnotetext{
${ }^{14}$ The remaining children were cared for in a variety of other arrangements. Data are based on the Survey of Income and Program Participation, as reported in the U.S. Bureau of the Census, Current Population Reports P70-30.
} 
either by the private market, or through non-market transactions within families or other social groups.

Child care for children in families where both parents work, or where a single parent works, is partly subsidized by the federal income tax code. The Child Care Credit provides a credit of $30 \%$ of child care costs for families with Adjusted Gross Incomes (AGIs) of less than $\$ 10,000$, and phases down to a credit rate of $20 \%$ for those with AGls of more than $\$ 28,000$. The maximum amount of expenditures to which the credit can be applies is limited to $\$ 2400$ for families with one child, and $\$ 4800$ for families with two or more children. There is also a federal tax provision that allows employees to pay for some child care expenses using dependent care accounts, which are offerred by some employers as part of cafeteria plan benefits. These accounts are more valuable than the child care credit for high-income households, but the total federal revenue loss associated with these accounts is small.

There is a sharp contrast between government involvement in the markets for child care and education. Most primary and secondary educational services in the United States are publicly-provided. In 1991, 90.7\% of elementary and secondary school students were enrolled in public schools, and per student expenditure averaged $\$ 4622$. At the college level, the public sector role is weaker but still strong: $78.7 \%$ of college students are enrolled in public colleges (see the 1993 Statistical Abstract of the United States, Table 228). Real public spending has increased during the last three decades, due both to the rising real costs of educational inputs and to increased inputs per student. Hanushek and Rivkin (1994) report that the pupil-teacher ratio in 
U.S. schools, for example, has declined from 26.3 in 1950 to 20.5 in 1970 to 15.4 in 1990.

Table 1 presents data on the estimated cost of various government programs that affect children, as compiled by the Congressional Budget Office, augmented with information on state and local educational spending. The table includes information on outlays for programs that are targetted only to preschoolers, such as Head Start and other compensatory education programs, as well as the share of broader programs, such as Food Stamps and Medicaid, that is received by children. The table shows that with the exception of spending on primary and secondary education, most of the programs targetted at children are relatively small. Moreover, most of these programs are targetted at children in poverty. The child care tax credit and the dependent care allowance are two of the few that are available to children in families above the poverty line. ${ }^{15}$

In light of the substantial flow of tax revenue to primary and secondary education in the United States, it is natural to ask whether concerns about market failure, a desire for redistribution, or other factors stimulated government support for education. The start of public education in the United States can be traced to a 1647 law of the Massachusetts Bay Colony directing any town with at least fifty families to hire a teacher, and any town with at least one hundred families to support a

\footnotetext{
${ }^{15}$ This situation contrasts sharply with that in some European countries, where governments provide child care to a substantial fraction of households. Ohlsson and Rosen (1994) report that in Sweden, 57 percent of pre-school children were in public day care in 1992, while a very high fraction of the rest were home with parents who were on paid parental leave.
} 
grammar school that could prepare young men to attend a university. The introduction of this law, reproduced in Johnson et al. (1986), does not suggest concern with either market failure or redistribution:

It being one chiefe project of $y$ ould deluder, Satan, to keepe men from the knowledge of $y$ Scriptures, ... evy towneship in this jurisdiction ... shall appoint one within their towne to teach all such children as shall resort to him to write and read ... (p.252).

While legislative language is not always a reliable guide to the factors that led to passage of a law, it may nevertheless be informative. This passage suggests a paternalistic desire to educate children. This was complemented by a concern that without schools, the Massachusetts Bay Colony would not be able to ensure a future supply of ministers.

The Massachusetts law was a model for public school legislation in other New England colonies, but it did not diffuse throughout the United States until the nineteenth century. In the South, for example, with large plantations and few towns with critical population mass, schooling for the children of wealthy planters was usually provided by private tutors. In the Middle Atlantic states, the school environment in the years following settlement involved a collection of private schools, many with religious affiliations. These states received many immigrants in the nineteenth century, and the growth of public schools in these states was justified in large part on the argument that such schools would facilitate assimilation of recent immigrants. Redistributive concerns did not appear to play an important role. The current concern about equality of access arose after public schools were well 
established in the United States. ${ }^{18}$

The evolution of public high schools in the United States also suggests that redistributive concerns were not central. When public high schools first became popular in the late 1800s, their incidence was regressive. Only the children of middle and upper income families could afford to remain in school beyond the elementary level, so they were the primary beneficiaries of these schools. Over time, the extent of participation in these schools grew, but similar arguments about regressive benefits have been applied to publicly-financed colleges and universities in the post-war period. ${ }^{17}$

The heavy reliance on local government provision of education in the United States, which contrasts with the situation in many Western European democracies, also undermines the importance of redistribution as an explanation for public provision of education. Because local governments depended heavily on the local property tax base for their revenue stream, different towns even within small metropolitan areas have historically devoted very different levels of resources to their public schools.

\subsection{Government Involvement in the Market for Medical Care}

Government involvement in the market for medical care is even more diverse

\footnotetext{
${ }^{18}$ West $(1967,1970)$ describes the expansion of publicly-provided education in the United States, emphasizing the role of a growing education bureaucracy in expanding the public sector's role.

${ }^{17}$ Hansen and Weisbrod (1969) present evidence suggesting that the net benefits of the University of California system are greater for high than for low-income households.
} 
than that with respect to child care and education. The federal government's Medicare and Medicaid programs involve substantial government financing for private purchases of health care, while the Veterans' Administration and many state and local governments operate a network of hospitals. Unlike teachers, however, most health care professionals work for private firms or non-profit institutions, although they are often subject to substantial government regulation.

Direct government spending on health services and supplies totalled $\$ 368$ billion in 1992, $45.5 \%$ of total health care outlays (Congressional Budget Office (1992)1. The government's spending share was substantially greater for hospital care and nursing home services. Government funds also represented more than sixty percent of the costs of medical research and medical facilities construction.

The government's share of the aggregate health care budget has grown substantially in the last three decades. In 1965, government spending accounted for $24.7 \%$ of health care outlays in the United States, with state and local governments accounting for more than half of this total $(13.2 \%)$. Since the enactment of Medicare and Medicaid in 1965, however, the federal government's role has increased. Federal spending accounted for $31.3 \%$ of all health care outlays in 1992, compared with $28 \%$ a decade earlier. Projections suggest even more rapid growth in the government's role in the future, as a consequence of both demographic change and continued growth in the relative cost of health care services.

Table 2 reports direct government spending on health care, as well as foregone revenue associated with several tax expenditures, for 1992. The single largest 
program supporting health care services is Medicare, which accounted fur mure lian $\$ 130$ billion and is projected to increase to more than $\$ 250$ billion by the end of this decade. There are also substantial foregone revenues associated with the tax expenditures for health insurance ( $\$ 45$ billion), as well as substantial tax expenditures from the federal income tax deduction for medical expenditures in excess of $7.5 \%$ of adjusted gross income, and deductions for charitable contributions to health care institutions. Direct government spending on health care is substantially less important than federal payments for health care from others. Federal outlays on the Veterans Administration health system, for example, were $\$ 14$ billion in 1992 , or $6.3 \%$ of total federal spending on health care.

The Medicare program has two parts. The first, Medicare Part A, provides hospital insurance for the elderly. This component of Medicare is funded with the revenues from a payroll tax on most employed workers, so it involves explicit intergenerational redistribution. Medicare Part B, or Supplementary Medical Insurance (SMII, provides insurance for outpatient services at hospitals and the costs of physician visits. SMI is an optional insurance program, and elderly individuals who choose to participate pay premiums that represent roughly one quarter of the cost of this insurance. The balance of the cost is financed from general revenues. Since all elderly individuals are eligible for the same benefits under Medicare, this aspect of the program redistributes from high- to low-income elderly households. However, Medicare is financed with a regressive flat-rate payroll tax, which has an opposite distributional effect. 
Tax subsidies for the purchase of health insurance and health care are the government provisions that affect the largest number of health care consumers. The exclusion of health insurance benefits from taxable income, and the tax rules allowing households to deduct medical expenses in excess of $7.5 \%$ of Adjusted Gross income when computing taxable income, reduce the price of health care for most taxpayers. The reduction in the after-tax price of insurance raises insurance coverage among employed households. While the decision not to tax the value of employer-provided health insurance was taken with the recognition that this would spur private insurance coverage, some of the most rapid growth in employer-provision of such insurance took place during the World War II, when wage controls made it difficult for employers to raise compensation in other ways.

Tax subsidies may encourage private spending, but they are weak instruments for redistribution across households. Since marginal tax rates increase with household income, high-income households receive the largest percentage subsidy to their purchases of both health insurance and medical care.

Medicaid, the other major government direct outlay program, pays for health insurance for poor households. The program is administered by the states subject to federal guidelines. Federal Medicaid spending is the most rapidly growing government health care outlay, exhibiting an annual growth rate of $15 \%$ between 1987 and 1990 . and $28 \%$ between 1990 and 1992 , although these growth rates are not expected to persist. A substantial part of the rapid growth in the early 1990 s was due to state gaming of federal reimbursement rules to maximize federal contribution to the state 
programs.

The history of government intervention in the medical marketplace suggests that redistributive concerns were the primary motivation for passage of the Social Security Act Amendments of 1965, which created Medicare and Medicaid. There is a long political history to the debate on public health insurance in the United States; see for example Starr (1982). A number of European countries, notably Germany and England, adopted universal health insurance laws in the late 19 th and early part of the 20th century. There was active discussion of such proposals just before World War 1 in the United States, as part of a battery of policies supported by the Progressives. Their motivation appeared to be specific egalitarianism, the provision of health insurance as a basic human right. The outbreak of World War I derailed legislative interest in these proposals, however, and, facing some opposition from doctors who did not want government to infringe their professional sovereignty, these proposals did not attract much attention in the fifteen years after World War 1.

The next wave of interest in national health insurance occurred during the New Deal, when President Roosevelt considered but rejected the idea of including health insurance in the legislation that became the Social Security Act of 1935. Once again, opposition from doctors was an important stumbling block. Although FDR never embraced national health insurance as a critical policy goal, President Truman did, and in 1948 he launched a major campaign to secure passage of a national health bill. The American Medical Association, by then a well-organized lobbying group, undertook an all-out campaign to block passage of this legislation. The debate took 
place during a period of great concern about Communist influence in the United States, and the AMA's labelling of the Truman proposals as "socialized medicine" and linking these proposals to Leninism proved successful in defeating them. The Social Security Amendments of 1950 did however stipulate that foderal matching funds would be provided for medical payments to health care providers for medical care to those on public assistance. This was a first step toward federal provision of medicai care for the needy, and it was expanded ten years later in the Kerr-Mills Act (1960).

The debate that led to passage of Medicare and Medicaid was joined in the mid1960 s, as part of the Great Society program. By this time concern about access to health care for low-income and elderly households had become acute, in part because rising health care costs made it more difficult for these groups to obtain care. Only $56 \%$ of the elderly had health insurance prior to the passage of Medicare. The critical political manouever in the Medicare debate was limiting the discussion to health care for the elderly. The evidence suggesting poorer access to health care for the elderly than for other age groups was difficult to dispute, and by focusing the program, objections from the AMA that this would lead to government control of doctors was blunted. Representative Wilbur Mills combined a Democratic proposal for mandatory hospital insurance (Medicare Part A) with a Republican proposal for a voluntary outpatient and physician care program (Medicare Part B) and produced legisiation that was supported by a majority of Congress.

The critical element in the debate leading to Medicare was a distributional concern with access to health care among specific groups. On this dimension, 
Medicare achieved its objectives. Davis and Schoen (1978) present some evidence that the ratio of physicians visits per year by those in high income and low income categories was more equal in 1975 than in 1964, before the passage of Medicare and Medicaid. The effect was less pronounced for the elderly than for younger groups.

To summarize this section, it is difficult to explain either the present structure of public involvement in education in the United States, or the historical evolution of the public sector's involvement, using either externality or redistributive arguments. Redistributive concerns do appear to play a greater role in defining government policy toward medical care. Concern about market failures in the medical marketplace does not appear to have played an important role in the rise of publicly-financed medical care in the United States.

\section{The Research Agenda}

The questions of whether particular markets may fail, and whether redistribution could in principle be carried out, receive far more discussion among economists than the questions of whether markets actually fail, whether government intervention in these markets improves or worsen matters, and whether various redistributive programs are actually successful. Yet the choice amongst various policies for government intervention depends on the actual performance of such policies. This concluding section outlines several areas where further research will yield high returns in informing the debate on choice of public policies in the fields of education and health care. 
42

First, because externalities are invoked to justify intervention in both of these markets, there is a pressing need to document the magnitude of the externalities, particularly those associated with consumption of education. It is important in this regard to assess whether the generation of externalities changes as the level of consumption changes, i.e., whether primary and secondary education yields larger or smaller externalities than higher education. If most externalities are generated by levels of educational input that individuals would choose to obtain without government subsidy, then the case for public intervention in the educational marketplace may be much weaker than is commonly believed. More generally, there is a need to quantify the importance of various imperfections that are listed as potential problems with the markets for education and health care, and to move beyond the discussion of reasons that might justify public intervention to reasons that do or de not.

Second, the efficiency of public providers of services, as opposed to that of private sector providers, requires further attention, since this is a key determinant of whether governments should "make or buy" services. The range of organizational forms in the medical care sector -. private hospitals, non-profit hospitals, as well as state- and federal-government run hospitals -- provides a wealth of data for comparing input choices and productivity. While many studies of public versus private production conclude that the public sector is a less efficient producer of various goods and services, these studies are often contaminated by various selection biases in the set of services provided by the government. Zeckhauser (1986) argues that in higher 
education, public institutions tend to function more like their nonprofit competitors than like other government bureaucracies. Further evidence on this issue for primary and secondary education, and for hospitals, would be valuable.

A third important issue, more concerned with political economy than the microeconomic analysis of government policy, concerns the basis of political support for redistributive policies toward children and the elderly. Spending on education represents redistribution to the young; spending on health care and health insurance transfers resources to the elderly. A number of commentators, including Preston (1984) and Kotlikoff and Gokhale (1993), have called attention to the rapid growth of transfers to the elderly, and the relative decline in society's investment in children. ${ }^{18}$ This may reflect more effective political activities of elderly voters than those who are concerned with children, or it may reflect the fact that more middle aged households are childless than without living parents. It is also possible that most middle-aged individuals know that they can expect to live well into their seventies and eighties, and to benefit from generous policies toward the elderly that are enacted today. These factors may explain the political reality of growing redistribution toward the elderly rather than children.

The current policy debates in both education and health care, including the discussions of school vouchers, increased state financing of schools, and a federal mandate for health insurance, suggest that the nature of government intervention in

\footnotetext{
${ }^{18}$ This may be partly related to the nature of current policies toward children and the elderly: education is provided by a public bureaucracy, medical care by the private market with public subsidy. Voters may not like expanding the bureaucracy.
} 
these markets is subject to continuing evaluation and potential change. This underscores the need for further investigation of both the arguments for government intervention in these areas, and the merits and demerits of alternative instruments for market intervention. 


\section{REFERENCES}

Aaron, H. 1994. Issues Every Plan to Reform Health Care Financing Must Confront. Journal of Economic Perspectives 8: 31-43.

Aaron, H. 1995. Reforming the Financing of Health Care: The Clash of Goals, Facts, and Ideology. In Individual and Social Responsibility, V. Fuchs, ed. Chicago: University of Chicago Press.

Arrow, K. 1963. Uncertainty and the Welfare Economics of Medical Care. American Economic Review 53: 941-973.

Ballard, C., J. Shoven, and J. Whalley. 1985. General Equilibrium Computations of the Marginal Welfare Costs of Taxes in the United States. American Economic Review 75: 128-138.

Becker, E. and F. Sloan. 1985. Hospital Ownership and Performance. Ecenomic Inquiry 23: 21-36.

Besley, T. and S. Coate. 1991. Public Provision of Private Goods and the Redistribution of Income. American Economic Review 81: 979-984.

Cohn, E. and T. Geske. 1990. The Economics of Education, Third Edition. Elmsford, NY: Pergamon Press.

Cutler, D. and L. Sheiner. 1994. Policy Options for Long Term Care. In Further Topics in the Economics of Aging, D. Wise, ed. Chicago: University of Chicago Press.

Davis, K. and C. Schoen. 1978. Health and the War on Poverty. Washington: Brookings Institution.

Frank, R. 1995. Consumption Externalities and the Financing of Social Services. In Individual and Social Respensibility, V. Fuchs, ed. Chicago: University of Chicago Press.

Friedman, M. 1962. Capitalism and Freedom. Chicago: University of Chicago Press.

Gornick, M., J. Greenberg, P. Eggers, and A. Dobson. 1985. Twenty Years of Medicare and Medicaid: Covered Populations, Use of Benefits, and Program Expenditures. Health Care Financing Review, 1985 Annual Supplement. Washington: U.S. Department of Health and Human Services.

Gruber, J. 1994. The Incidence of Mandated Maternity Benefits. American Economic Review 84: 622-641. 
Gruber, J. and J. Poterba. 1994. Tax Incentives and the Decision to Purchase Health Insurance: Evidence from the Self-Employed. Quarterly Journal of Economics 109: 701-733.

Hansen, W. and B. Weisbrod. 1969. Benefits, Costs, and Finance of Public Higher Education. Chicago: Markham Publishing Company.

Hansmann, H. 1995. Organization of Production in the Human Services. In Individual and Secial Responsibility, V. Fuchs, ed. Chicago: University of Chicago Press.

Hanushek, E. and S. Rivkin. 1994. Understanding the 20th Century Explosion in U.S. School Costs. Mimeo, University of Rochester.

Henderson, J., P. Mieszkowski, and Y. Sauvageau. 1978. Peer Group Effects and Educational Production Functions. Journal of Public Economics 10: 97-106.

Himes, C. 1994. Parental Caregiving by Adult Women. Research on Aging 16:191211.

Johnson, J., H. Collins, V. Dupuis, and J. Johansen. 19XX. Introduction to the Foundations of American Education. Boston: Allyn and Bacon.

Keeler, E., J. Buchanan, J. Rolph, et al. 1988. The Demand for Episodes of Treatment in the Health Insurance Experiment. Report R-3454-HHS. Santa Monica, CA: RAND Corporation.

Kotlikoff, L. and J. Gokhale. 1993. The Equity of Social Services Provided to Children and Senior Citizens. Boston: Working Paper \#20, Boston University Department of Economics.

Lindsay, C. 1976. A Theory of Government Enterprise. Journal of Political Economy 84: 1061-1077.

Long, S. and M. Marquis. 1992. Gaps in Employment Based Health Insurance: Lack of Supply or Lack of Demand? In Health Benefits and the Workforce. Washington: U.S. Department of Labor, Pension and Welfare Benefits Administration.

McKean, R. and J. Minasian. 1966. On Achieving Parte Optimality - Regardless of Costl Western Economic Journal 5: 14-23.

Nichols, A. and R. Zeckhauser. 1981. Targetting Transfers Through Restrictions on Recipients. American Economic Review 72: 372-377. 
Ohlsson, H. and S. Rosen. 1994. Public Employment, Taxes, and the Welfare State in Sweden. Mimeo, University of Chicago.

Peltzman, S. 1973. The Effect of Government Subsidies-in-Kind on Private Expenditures: The Case of Higher Education. Journal of Political Economy 81: $1-27$.

Preston, S. 1984. Children and the Elderly: Divergent Paths for America's Dependents. Demography 21: 435-457.

Ravitch, D. 1986. American Education: Public and Private Responsibilities. In American Society: Public and Private Responsibilities, W. Knowlton and R. Zeckhauser, eds. Cambridge: Ballinger Publishing Company.

Rosen, H. 1992. Public Finance, Third Edition. Homewood, IL: Kichard U. Irwin.

Rothschild, M. and J. Stiglitz. 1976. Equilibrium in Competitive Insurance Markets: An Essay on the Economics of Imperfect Information. Quarterly Journal of Economics 90: 629-649.

Schulz, R., J. Greenley, and R. Peterson. 1984. Differences in the Direct Costs of Public and Private Acute Inpatient Psychiatric Services. Inquiry 21: 380-393.

Sonstelie, J. 1982. The Welfare Cost of Free Public Schools. Journal of Political Economy 90: 794-808.

Starr, P. 1982. The Social Transformation of American Medicine. New York: Basic Books.

Stiglitz, J. 1988. Economics of the Public Sector (2nd Edition). New York: W.W. Norton.

Summers, L. 1989. Some Simple of Economics of Mandated Benefits. American Economic Review 79 (May): 177-184.

Tobin, J. 1970. On Limiting the Domain of Inequality. Journal of Law and Economics 13 (October): 263-277.

U.S. Congressional Budget Office. 1992. Projections of National Health Expenditures. Washington: Congressional Budget Office.

Vining, A. and A. Boardman. 1992. Ownership vs. Competition: Efficiency in Public Enterprise. Public Choice 73: 205-239. 
Weitzman, M. 1974. Prices vs. Quantities. Review of Economic Studies 41: 447491.

West, E. 1967. The Political Economy of American Public School Legislation. Jeurnal of Law and Economics 10: 101-128.

West, E. 1970. Education and the State Second Edition. London: Institute for Economic Affairs.

Wilson, C. 1980. The Nature of Equilibrium in Markets with Adverse Selection. Bell Journal of Economics (Spring): 108-130.

Wolf, C. 1986. Markets or Governments: Choosing Between Imperfect Alternatives. Working Paper N-2505-SF. Santa Monica, CA: RAND Corporation.

Zeckhauser, R. 1986. The Muddled Responsibilities of Public and Private America. In American Society: Public and Private Responsibilities, W. Knowlton and R. Zeckhauser, eds. Cambridge: Ballinger Publishing Company. 
Table 1: Government Spending Programs Directed Toward Children, 1990

Program Description

Spending (\$ Billion)

Cash Transfers

Social Security

Supplemental Security Income

8.9

Aid to Families with Dependent Children

1.4

Veterans Compensation

12.9

Earned Income Tax Credit

0.5

4.0

In-Kind Transfers

Food Stamps

7.3

Child Nutrition

7.1

Medicare

Medicaid (mult by 1.755 to get 12.63 )

0.1

Housing Assistance

7.2

Low Income Energy Assistance

7.5

0.6

Federal Education Programs

Compensatory Education

Impact Aid

4.5

Education for the Handicapped

0.8

Other Education Programs

1.6

1.4

Other Federal Programs

Child Support Programs

0.5

Human Development (Head Start and Other)

1.8

Foster Care/Adoption Assistance

1.6

Maternal and Child Health \& Immunization

0.8

Summer Youth Employment

0.7

Other

0.6

Revenue Loss from Tax Credits

Earned Income Tax Credit

Dependent Care Credit

2.4

Exclusion of Employer-Provided Dependent Care

0.5

Exclusion of Benefits. Provided Through Cafeteria Plans

3.1

State and Local Education Spending

194.0

Source: U.S. House of Representatives, Committee on Ways and Means, 1993 Green Book: Qverview of Entitlement Programs: Background Material and Data on Programs within the Jurisdiction of the Committee on Ways and Means (U.S. Government Printing Office: 1993), pp. 1566-7, and author's tabulations. 
Table 2: Government Spending on Medical Care, 1992

Direct Government Spending

$\begin{array}{lc}\text { Federal } & \$ 253 \\ \text { - Medicare } & 136 \\ \text { - Medicaid } & 70 \\ \text { - Other (VA, NIH) } & 46 \\ & \\ \text { State \& Local } & 115 \\ \text { - Medicaid } & 53 \\ \text { - Other (Workers' Compensation, Public Hospitals) } & 62\end{array}$

Tax Expenditures on Health (Federal \& State)

Exemption of Employer-Provided Health Insurance 45

$\begin{array}{ll}\text { Untaxed Medicare Benefits } & 8\end{array}$

Deductibility of Medical Expenses 3

Other (Tax-Exempt Debt, Charitable Deductions) 4

Total $\$ 428$

Source: Author's tabulations based on information in CBO (1992), Tables 11 and B-2. 